\title{
HAK KEBEBASAN BERPENDAPAT DALAM HUBUNGANNYA DENGAN PENCEMARAN NAMA BAIK MENURUT KUHP; PERSPEKTIF TEORI MAQÂȘID SHARÎ'AH
}

\author{
Moh. Faizur Rohman \\ Universitas Islam Negeri Sunan Ampel Surabaya, Indonesia \\ E-mail: faza_veiro@yahoo.co.id
}

\begin{abstract}
Human rights are often echoed by various parties are sometimes opposed to each other. Many journalists who exercised the right to freedom of expression expressed the opinion that the right has been protected by the 1945 Constitution article $28 \mathrm{E}$ (3), precisely resulting in a criminal offense of defamation for those who do not like it. Defamation articles in the Criminal Code are often regarded as a powerful weapon against a criticism as a form of antipathy against criticism. Therefore, there should be efforts to classify the forms of the use of rights and forms of criminal acts. and will be seen from the standpoint of maqâsid sharîah. Through approach statue approach, and case approach, obtained that the law has protected the rights of everyone in expressing opinions. Every person shall have the right and freedom to express opinions but such rights shall not infringe the rights of others. In maqâsid is guaranteed and protected self-esteem, the soul for every human being is contained in the principle of bifdu al-nafs wa al-ird. Therefore, in every opinion, communicate and socialize should pay attention to the rights of others is the dignity of one's dignity to create a balanced and harmonious life.
\end{abstract}

Keywords:: HAM, Defamation, KUHP, Freedom Opinion, Maqâsid Sharìah

\section{Pendahuluan}

Indonesia adalah Negara Hukum. hal tersebut dapat terlihat jelas dalam Amandemen UUD 1945 Pasal 1 ayat (3). ${ }^{1}$ Sebagai salah satu syarat

\footnotetext{
1 UUD NRI Tahun 1945 Pasal 1 Ayat (3), Lampiran Dalam Buku Moh. Mahfud MD, Demokrasi Dan Konstitusi Di Indonesia, Studi Tentang Interaksi Politik Dan Kehidupan Ketatanegaraan, (Yogjakarta: Liberty, 2000), 194.
} 
negara hukum yang demokratis harus ada jaminan HAM dalam konstitusi maupun dalam semua peraturan perundang-undangan.

Salah satu jaminan hak yang diatur dalam undang-undang adalah hak untuk berpendapat, menyatakan pikiran dan berserikat (UUD'45 Pasal 28 E, F), namun dalam perkembangannya banyak para penulis terkena imbas atas tulisannya. Tulisan yang berisi kritikan-kritikan konstruktif malah menjadi boomerang bagi sang penulis itu sendiri, tulisan yang awal mula bertujuan untuk membangun kearah yang lebih baik lagi malah menjadi suatu senjata bagi orang lain yang tidak suka terhadap suatu kritikan, yang pada akhirnya melaporkan kritikan tersebut menggunakan delik aduan dengan tuduhan pencemaran nama baik.

Mengkritik merupakan salah satu tindak upaya dalam membangun sebuah organisasi atau sikap untuk menjadi yang lebih baik lagi. Satu sisi ingin membangun bangsa dengan kritikan konstruktif melalui mediamedia yang ada, akan tetapi sisi lain adanya suatu ancaman pasal pidana pencemaran nama baik yang mengancam setiap kritikan yang diajukan. Sebagaimana yang terjadi dalam kasus yang dialami oleh kolumnis surat kabar dimana seorang kolumnis surat kabar menulis di salah satu media massa yang berisi mengenai kritikan terhadap kebijakan salah satu lembaga pemerintahan karena dianggap tidak sesuai dengan jalan pikirannya, akan tetapi setelah tulisannya dimuat dan dipublikasikan ternyata kolumnis tersebut dilaporkan dengan tuduhan pencemaran nama baik.

Dari satu sisi undang-undang di Negara Indonesia telah mengakui dan melindungi hak setiap orang untuk bebas menyatakan pendapat, akan tetapi di sisi lain banyak orang yang merasa tidak suka akan kritikan dengan "sesuka hati" memakai senjata pasal pencemaran nama baik untuk membungkam kritikan tersebut.

Pasal Pencemaran Nama Baik yang terdapat dalam KUHP seringkali dianggap sebagai alat untuk membungkam kebebasan berbicara. Hal ini dikarenakan KUHP merupakan produk belanda dan digunakan untuk menakut-nakuti warga pribumi pada awalnya. Oleh karena itu pasal pencemaran dalam KUHP tersebut pernah dibawa dihadapan Mahkamah Konstitusi untuk diuji materi, karena dianggap bertentangan dengan UUD 1945 dalam hal kebebasan mengeluarkan pikiran menyatakan pendapat (Pasal $28 \mathrm{E})$.

Akan tetapi Mahkamah Konstitusi berpendapat bahwa jika pasal-pasal pencemaran nama baik dalam KUHP yang dimohonkan pengujian itu meniadakan atau menghilangkan hak atas kebebasan menyatakan pikiran dan sikap sesuai dengan hati nurani, hak untuk mengeluarkan pendapat, 
dan hak untuk bebas berkomunikasi, maka menurut Mahkamah, anggapan demikian tidaklah benar. Konstitusi menjamin hak-hak tersebut dan karena itu negara wajib melindunginya. Namun, pada saat yang sama negara pun wajib melindungi hak konstitusional lain yang sama derajatnya dengan hak-hak tadi, yaitu hak setiap orang atas kehormatan dan martabat sebagaimana diatur Pasal 28G UUD 1945.

Muncullah suatu putusan Mahkamah Konstitusi Nomor 14/PUUVI/2008 yang terkait dengan uji materi dalam pasal Kitab UndangUndang Hukum Pidana (KUHP) terhadap UUD 1945. Mengenai pasal 207 KUHP, 310 ayat (1) KUHP, 310 ayat (2) KUHP, 311 ayat (1), 316 KUHP terkait ancaman pidana bagi pelaku pencemaran nama baik dianggap bertentangan dengan UUD 1945 pasal 27 ayat (1), 28E ayat (2), $28 \mathrm{E}$ ayat (3), $28 \mathrm{~F}$ yang menjamin kebebasan berpendapat yang dilindungi oleh Undang-Undang Dasar karena merupakan jaminan atas hak asasi manusia.

Oleh pemohon dalam masalah ini, pasal 207 KUHP, 310 ayat (1) KUHP, 310 ayat (2) KUHP, 311 ayat (1), 316 KUHP dianggap bertentangan dengan Pasal 27 ayat (1), Pasal 28E ayat (2), Pasal 28E ayat (3), dan Pasal 28F UUD 1945 yang menjamin kebebasan berserikat, berkumpul dan mengeluarkan pendapat. Sebagai warga Negara yang hak asasinya telah dijamin oleh Negara melalui konstitusi dalam UndangUndang Dasar merasa haknya telah dilanggar oleh pasal KUHP terkait pencemaran nama baik. Menurut mereka hak untuk mengeluarkan pendapat telah dirampas dengan adanya pemberlakuan pidana pasal pencemaran nama baik dalam KUHP. Hak-hak konstitusionalnya yang telah dijamin oleh Pasal 27 ayat (1), Pasal 28E ayat (2), Pasal 28E ayat (3), dan Pasal 28F UUD 1945 telah dirugikan oleh pemberlakuan pidana penjara pada Pasal 207, Pasal 316, Pasal 310 ayat (1), Pasal 310 ayat (2), dan Pasal 311 ayat (1) KUHP.

Sanksi pidana penjara terhadap ketentuan tindak pidana dalam KUHP tersebut, dianggap telah bertentangan dengan kebebasan menyatakan pikiran dan sikap sesuai dengan hati nurani [Pasal 28E ayat (2) UUD 1945]; kebebasan mengeluarkan pendapat [Pasal 28E ayat (3) UUD 1945]; dan kebebasan berkomunikasi [Pasal 28F UUD 1945]. Delik penghinaan seringkali dijatuhkan kepada warga negara Indonesia yang menggunakan hak konstitusionalnya untuk menyatakan pikiran dan pendapat, serta mereka yang melakukan aktivitas penyebarluasan informasi.

UU Nomor 39 Tahun 1999 tentang Hak Asasi Manusia dalam Pasal 14 ayat (2) menyatakan bahwa Setiap orang berhak untuk mencari, 
memperoleh, memiliki, menyimpan, mengolah, dan menyampaikan informasi dengan menggunakan segala jenis sarana yang tersedia. ${ }^{2} \mathrm{Hal}$ ini secara kasat mata menyatakan bahwa setiap orang berhak menyampaikan informasi tanpa dibatasi oleh hak-hak yang lain.

Dalam satu sisi, pencemaran nama baik adalah melanggar hak orang lain, akan tetapi dari sisi lain mengenai kebebasan berserikat, berpendapat dan menyatakan pikiran juga merupakan hak setiap orang sebagai warga Negara sebagai dasar atas hak asasi manusia.

Oleh karena itu perlu digali lebih dalam mengenai cara berpendapat maupun berekspresi yang bagaimana yang tidak termasuk dalam kategori pencemaran nama baik sehingga tidak muncul rasa khawatir terhadap pasal pencemaran nama baik dalam KUHP tersebut. Dan sebaliknya yaitu mengeluarkan pendapat dengan cara dan sikap yang bagaimana pula dimana hal tersebut dapat dikategorikan dalam pencemaran nama baik sehingga kita harus hati-hati dalam berekspresi serta dapat mempertanggung jawabkan perbuatan atas kritikan atau pendapat yang telah dikeluarkan.

Untuk mengurai permasalahan tersebut, maka perlu diketahui mengenai bagaimana sebenarnya konsep HAM dalam ketatanegaraan Negara Indonesia baik dalam UUD 1945 maupun dalam UU 39/1999 tentang HAM yang akan lebih spesifik ke dalam konsep kebebasan mengeluarkan pendapat disertai dengan batasan-batasan yang telah ditentukan, sehingga nantinya akan diketahui hak-hak dasar mana dari setiap orang yang tercederai terkait dengan pencemaran nama baik yang telah diatur dalam pasal-pasal dalam KUHP. Kemudian dicari konsep dasar melalui teori pisau analisis Maqâșid Sharìah,

\section{Hak Kebebasan Berpendapat dan Pencemaran Nama Baik dalam KUHP}

Yang dimaksud dengan "menghina" adalah "menyerang kehormatan dan nama baik seseorang". Dimana orang yang dihina akan terkena dampak berupa perasaan malu. ${ }^{3}$ Menghina juga bisa diartikan meodai reputasi seseorang ataupun sekelompok orang dengan cara-cara yang tidak baik seperti pernyataan yang tidak berdasarkan fakta. ${ }^{4}$

Pada prinsipnya, mengenai pencemaran nama baik diatur dalam KUHP, Bab XVI tentang Penghinaan yang termuat dalam Pasal 310 s.d

\footnotetext{
2 UU RI Nomor 39 Tahun 1999 tentang Hak Asasi Manusia, pdf.

${ }^{3}$ wikipedia.org/wiki/Ucapan_kebencian, akses tanggal 27-06-2015

${ }_{4}$ Tjipta Lesmana, Pencemaran Nama Baik dan Kebebasan Pers Antara Indonesia dan Amerika, (Jakarta: Rika Press, 2005), 27
} 
321 KUHP. Melihat pada penjelasan R. Soesilo dalam Pasal 310 KUHP, dapat kita lihat bahwa KUHP membagi enam macam penghinaan, yakni: ${ }^{5}$

Pertama, Penistaan (Pasal 310 ayat (1) KUHP). Menurut R. Soesilo, supaya dapat dihukum menurut pasal ini, maka penghinaan itu harus dilakukan dengan cara "menuduh seseorang telah melakukan perbuatan tertentu" dengan maksud agar tuduhan itu tersiar (diketahui oleh orang banyak). Perbuatan yang dituduhkan itu tidak perlu suatu perbuatan yang boleh dihukum seperti mencuri, menggelapkan, berzina dan sebagainya, cukup dengan perbuatan biasa, sudah tentu suatu perbuatan yang memalukan.

Kedua, Penistaan dengan surat (Pasal 310 ayat (2) KUHP). Menurut R. Soesilo sebagaimana dijelaskan dalam penjelasan Pasal 310 KUHP, apabila tuduhan tersebut dilakukan dengan tulisan (surat) atau gambar, maka kejahatan itu dinamakan "menista dengan surat". Jadi seseorang dapat dituntut menurut pasal ini jika tuduhan atau kata-kata hinaan dilakukan dengan surat atau gambar.

Ketiga, Fitnah (Pasal 311 KUHP). Merujuk pada penjelasan R. Soesilo dalam Pasal 310 KUHP, perbuatan dalam Pasal 310 ayat (1) dan ayat (2) KUHP tidak masuk menista atau menista dengan tulisan (tidak dapat dihukum), apabila tuduhan itu dilakukan untuk membela kepentingan umum atau terpaksa untuk membela diri. Dalam hal ini hakim barulah akan mengadakan pemeriksaan apakah betul-betul penghinaan itu telah dilakukan oleh terdakwa karena terdorong membela kepentingan umum atau membela diri, jikalau terdakwa meminta untuk diperiksa (Pasal 312 KUHP). Apabila soal pembelaan itu tidak dapat dianggap oleh hakim, sedangkan dalam pemeriksaan itu ternyata, bahwa apa yang dituduhkan oleh terdakwa itu tidak benar, maka terdakwa tidak disalahkan menista lagi, akan tetapi dikenakan Pasal 311 KUHP (memfitnah).

Keempat, Penghinaan ringan (Pasal 315 KUHP). Penghinaan seperti ini dilakukan di tempat umum yang berupa kata-kata makian yang sifatnya menghina. R Soesilo, dalam penjelasan Pasal 315 KUHP, mengatakan bahwa jika penghinaan itu dilakukan dengan jalan lain selain "menuduh suatu perbuatan", misalnya dengan mengatakan "anjing", "asu", "sundel", "bajingan" dan sebagainya, masuk Pasal 315 KUHP dan dinamakan "penghinaan ringan".

\footnotetext{
5 Penjelasan R. Soesilo. 1991. Kitab Undang-Undang Hukum Pidana (KUHP) Serta Komentar-Komentarnya Lengkap Pasal Demi Pasal. Politeia: Bogor. Dalam http://www.hukumonline.com/ klinik/detail/lt517f3d9f2544a/perbuatan-perbuatan-yangtermasuk-pencemaran-nama-baik
} 
Penghinaan ringan ini juga dapat dilakukan dengan perbuatan. Menurut R. Soesilo, penghinaan yang dilakukan dengan perbuatan seperti meludahi di mukanya, memegang kepala orang Indonesia, mendorong melepas peci atau ikat kepala orang Indonesia. Demikian pula suatu sodokan, dorongan, tempelengan, dorongan yang sebenarnya merupakan penganiayaan, tetapi bila dilakukan tidak seberapa keras, dapat menimbulkan pula penghinaan.

Kelima, Pengaduan palsu atau pengaduan fitnah (Pasal 317 KUHP). R. Sugandhi, S.H. dalam bukunya yang berjudul Kitab Undang-Undang Hukum Pidana Berikut Penjelasannya (hal. 337) memberikan uraian pasal tersebut, yakni diancam hukuman dalam pasal ini ialah orang yang dengan sengaja: (a) memasukkan surat pengaduan yang palsu tentang seseorang kepada pembesar negeri; dan (b) menyuruh menuliskan surat pengaduan yang palsu tentang seseorang kepada pembesar negeri sehingga kehormatan atau nama baik orang itu terserang.

Keenam, Perbuatan fitnah (Pasal 318 KUHP). Menurut R. Sugandhi, S.H., terkait Pasal 318 KUHP, yang diancam hukuman dalam pasal ini ialah orang yang dengan sengaja melakukan suatu perbuatan yang menyebabkan orang lain secara tidak benar terlibat dalam suatu tindak pidana, misalnya: dengan diam-diam menaruhkan sesuatu barang asal dari kejahatan di dalam rumah orang lain, dengan maksud agar orang itu dituduh melakukan kejahatan.

Adapun pasal pasal yang merupakan penghinaan di dalam Kitab Undang-Undang Hukum Pidana yaitu: (1) Pasal 207, 208, 209 Penghinaan terhadap Penguasa dan Badan Usaha Umum diancam pidana 6 tahun penjara. (2) Pasal 310, 311, 315, 316 Penyerangan atau pencemaran kehormatan atau nama baik seseorang, tuduhan dengan tulisan, diancam pidana 9 bulan, dan 16 bulan penjara. (3) Pasal 317 Fitnah pemberitahuan palsu, pengaduan palsu, diancam pidana 4 tahun penjara. Dan (4) Pasal 320, 321 Penghinaan atau pencemaran nama baik terhadap orang mati, diancam pidana 4 bulan penjara

Di dalam Pasal 27 Undang-Undang Nomor 11 Tahun 2008 tentang Informasi dan Transaksi Elektronik ada beberapa larangan yang berupa pidana menyatakan bahwa: ${ }^{6}$

Pertama, Setiap orang dengan sengaja dan tanpa hak mendistribusikan dan/atau mentrasnmisikan dan/atau membuat dapat diaksesnya

${ }^{6}$ Undang-Undang Nomor 11 Tahun 2008 tentang Informasi dan Transaksi Elektronik. 
Informasi Elektronik dan/atau Dokumen Elektronik yang memiliki muatan yang melanggar kesusilaan.

Kedua, Setiap orang dengan sengaja dan tanpa hak mendistribusikan dan/atau membuat dapat diaksesnya Informasi Elektronik dan/atau Dokumen Elektronik yang memiliki muatan perjudian.

Ketiga, Setiap orang dengan sengaja dan tanpa mendistribusikan dan/atau mentransmisikan dan/atau membuat dapat diaksesnya Informasi Elektronik dan/atau Dokumen Elektronik yang memiliki muatan penghinaan dan/atau pencemaran nama baik.

Keempat, Setiap orang dengan sengaja dan tanpa mendistribusikan dan/atau mentransmisikan dan/atau membuat dapat diaksesnya Informasi Elektronik dan/atau Dokumen Elektronik yang memiliki muatan pemerasan dan/atau pengancaman.

Ada tiga sifat delik pencemaran nama baik yang harus diperhatikan: ${ }^{7}$ Pertama, delik yang bersifat subyektif. Yaitu penilaian terhadap pencemaran nama baik bergantung kepada orang atau pihak yang diserang nama baiknya. Karena itu, pencemaran nama baik merupakan delik aduan yang hanya bisa diproses oleh polisi jika ada pengaduan dari orang atau pihak yang merasa nama baiknya dicemarkan. Oleh karena itu, tolak ukur pencemaran nama baik dalam penilaian ini sangat subjektif tergantung individu masing-masing.

Kedua, pencemaran nama baik merupakan delik penyebaran. Artinya, substansi yang berisi pencemaran disebarluaskan kepada umum atau dilakukan di depan umum oleh pelaku. Unsur hinaan atau pencemaran nama baik seseorang yang disimpan dan dibaca secara pribadi tanpa disebarluaskan secara umum tidak menjadikan hal tersebut menjadi sebuah suatu tindakan pencemaran nama baik. Kecuali konten yang berisi pencemaran nama baik terhadap seseorang tersebut karena kecerobohan pribadi telah tersebar luas secara umum meskipun hal itu sebenarnya adalah koleksi pribadi.

Ketiga, orang yang melakukan pencemaran nama baik dengan menuduh suatu hal yang dianggap menyerang nama baik seseorang atau pihak lain harus diberi kesempatan untuk membuktikan tuduhan itu. Harus ada klarifikasi bahwa memang orang tersebut benar-benar telah melakukan tindakan pencemaran nama baik baik berupa lisan maupun tulisan.

\footnotetext{
7 Eddy OS Hiariej, (Guru Besar Hukum Pidana Fakultas Hukum UGM), Memahami Pencemaran Nama Baik, dalam http://beniharmoniharefa.blogspot.com/2011/03/ memahami-pencemaran-nama-baik.html, Dimuat pada Harian KOMPAS, 5 Juni 2009
} 
Pencemaran nama baik merupakan tindakan pelanggaran HAM yang bersifat ringan. Pencemaran nama baik merupakan pelanggaran terhadap harga diri, harkat dan martabat seseorang. Oleh karena itu harus ada batasan dalam menyampaikan pendapat supaya tidak sampai melanggar harga diri seseorang dengan suatu tindakan pencemaran nama baik.

Individu yang kritis terhadap permasalahan yang terjadi di dalam masyarakat harus tetap memperhatikan etika dalam mengemukakan pendapat. Karena kebebasan yang diperoleh melalui HAM pun akan tetap dibatasi dengan etika dan hubungan inter-personal yang berlangsung di dalam masyarakat.

Pencemaran atau penghinaan nama baik orang lain melanggar HAM karena bisa menimbulkan resiko kepada yang dihina antara lain: ${ }^{8}$ Pertama, orang yang dihina atau dicemarkan akan merasa malu akan kehormatan harga dirinya. Hal ini akan menimbulkan tekanan mental yang sangat luar biasa dialami orang tersebut. Pada akhirnya malu untuk bersosialisasi terhadap lingkungannya sehingga hak untuk hidup nyaman, untuk mendapatkan tempat tinggal dan kehidupan yang layak tidak ia dapatkan.

Kedua, Pihak yang dihina atau dicemarkan berkemungkinan dikucilkan dari masyarakat di sekitarnya. Ini juga akan berdampak psikologis kepada pihak yang dihina tersebut. Lebih-lebih hal yang dituduhkan ternyata tidak terbukti kebenarannya dan ternyata merupakan fitnah. Bisa berujung pada tekanan mental yang parah, merasa tidak percaya diri, mengalami gangguan kesehatan akibat jiwa yang tertekan, dan bahkan lebih parahnya lagi, mengakibatkan sang korban bisa bunuh diri karena tidak tahan lagi dengan keadaan tertekan yang dialami.

Ketiga, Jika pihak yang dihina/dicemarkan nama baiknya adalah suatu perusahaan, dapat menimbulkan kerugian bagi perusahaan tersebut. Karena akan menimbulkan rasa ketidakpercayaan dari para anggotanya.

\section{Kebebasan Berpendapat yang Diatur dalam UU Nomor 39 Tahun 1999 Tentang HAM Hubungannya dengan Pencemaran Nama Baik dalam KUHP.}

Hak asasi merupakan hak dasar bagi setiap individu manusia itu sendiri, dimana dalam setiap diri manusia terdapat kebutuhan-kebutuhan mendasar yang harus dihargai, dihormati dan dijaga. yang berasal dari kemanusiaan setiap insan dan hak-hak itu bertujuan untuk menjamin martabat setiap manusia sebagai manusia itu sendiri.

\footnotetext{
8 http://www.kompasiana.com/hoshizora/pelanggaran-ham-pencemaran-nama-baik-seseo rang-kelompok-di-sosmed.
} 
Dalam salah satu hak yang telah dikemukakan oleh Franklin D. Roosevelt adalah dijaminnya kebebasan untuk berbicara dan mengemukakan pendapat.

Hal tersebut juga telah dijamin dalam UUD 1945 dalam pasal 28 E (3) dan asal $28 \mathrm{~F}$ yang menyatakan bahwa setiap orang berhak untuk kebebasan berserikat, berkumpul dan mengeluarkan pendapat, juga berhak berkomunikasi dan memperoleh informasi untuk mengembangkan pribadi dan lingkungan sosialnya, serta berhak untuk mencari, memperoleh, memiliki, menyimpan, mengolah, dan menyampaikan informasi dengan menggunakan segala jenis saluran yang tersedia.

Hal itu juga yang telah dijamin dalam UU No. 39 Tahun 1999 tentang Hak Asasi Manusia, dalam pasal 14, 23, 24, 25 yang menyatakan perlindungan dalam kebebasan berekspresi dan menyampaikan pendapat maupun menyampaikan informasi.

Jaminan atas hak untuk mengeluarkan pernyataan dapat dirujuk dari: Pertama, Deklarasi Universal Hak Asasi Manusia, 1948 Pasal 19: "Setiap orang berhak atas kebebasan beropini dan berekspresi; hak ini meliputi kebebasan untuk memiliki opini tanpa intervensi serta untuk mencari, menerima, dan mengungkapkan informasi serta gagasan melalui media apa pun dan tidak terikat garis perbatasan".

Kedua, Undang-Undang Dasar RI (Perubahan Kedua) Pasal 28 E (3): "setiap orang berhak atas kebebasan berserikat, berkumpul, dan mengeluarkan pendapat" dan Pasal 28F: "Setiap orang berhak untuk berkomunikasi dan memperoleh informasi untuk mengembangkan pribadi dan lingkungan sosialnya, serta berhak untuk mencari, memperoleh, memiliki, menyimpan, mengolah, dan menyampaikan informasi dengan menggunakan segala jenis saluran yang tersedia"

Ketiga, Undang-Undang RI No 39 tahun 1999 Tentang Hak Asasi Manusia:

\section{Pasal 14}

1. Setiap orang berhak untuk berkomunikasi dan memperoleh informasi yang diperlukan untuk mengembangkan pribadi dan lingkungan sosialnya.

2. Setiap orang berhak untuk mencari, memperoleh, memiliki, menyimpan, mengolah, dan menyampaikan informasi dengan menggunakan segala sarana yang tersedia.

\section{Pasal 23}

1. Setiap orang bebas untuk memilih dan mempunyai keyakinan politiknya. 
2. Setiap orang bebas untuk mempunyai, mengeluarkan dan menyebarluaskan pendapat sesuai hati nuraninya, secara lisan dan atau tulisan melalui media cetak maupun elektronik dengan memperhatikan nilai-nilai agama, kesusilaan, ketertiban, kepentingan umum, dan keutuhan negara.

\section{Pasal 24}

1. Setiap orang berhak untuk berkumpul, berapat, dan berserikat untuk maksud-maksud damai.

2. Setiap warga negara atau kelompok masyarakat berhak mendirikan partai politik, lembaga swadaya masyarakat atau organisasi lainnya untuk berperan serta dalam jalannya pemerintahan dan penyelenggaraan negara sejalan dengan tuntutan perlindungan, penegakan, dan pemajuan hakasasi manusia sesuai dengan ketentuan peraturan perundang-undangan.

\section{Pasal 25}

"Setiap orang berhak untuk menyampaikan pendapat dimuka umum, termasuk hak untuk mogok sesuai dengan ketentuan perundangundangan"

Akan tetapi banyak kasus-kasus pidana yang berasal dari kebebasan menyampaikan pendapat. Dalam menggunakan hak berpendapat banyak sekali dianggap sebagai salah satu cara untuk menjatuhkan diri seseorang atau menjatuhkan sebuah kewibawaan maupun kedudukan. Oleh karena itu seringkali kebebasan menyampaikan pendapat ini di anggap sebuah ancaman oleh sebagian orang. Yang pada akhirnya mengajukan delik aduan sebagai tindak pidana pencemaran nama baik.

Memang dalam undang-undang telah dicantumkan mengenai perlindungan suatu kehormatan atas harga diri seseorang. Akan tetapi bukan berarti kita tidak bisa serta merta langsung bertindak otoriter atas sikap antipati terhadap suatu kritikan.

Hak dalam menyatakan kebebasan pendapat yang dijamin oleh undang-undang telah dibatasi oleh pasal-pasal yang tercantum dalam KUHP yaitu terkait dengan pasal-pasal pencemaran nama baik, fitnah, penghinaan dan tuduhan palsu antara lain dalam pasal: (1) Pasal 207, 208, 209 KUHP; Penghinaan terhadap Penguasa dan Badan Usaha Umum diancam pidana 6 tahun penjara. (2) Pasal 310, 311, 315, 316 KUHP; Penyerangan/pencemaran kehormatan atau nama baik seseorang, tuduhan dengan tulisan, diancam pidana 9 bulan, dan 16 bulan penjara. (3) Pasal 317 KUHP; Fitnah pemberitahuan palsu, pengaduan palsu, diancam pidana 4 tahun penjara. (4) Pasal 320, 321 KUHP; Penghinaan 
atau pencemaran nama baik terhadap orang mati, diancam pidana 4 bulan penjara.

Sebenarnya dalam UU tentang pers telah diatur bagaimana cara menyampaikan dan menyajikan suatu pendapat ketika dipublikasikan. Salah satu diantaranya adalah harus menjaga etika dan estetika dalam berbicara maupun menyampaikan pendapat. Tidak merusak harga diri orang lain dan tidak menimbulkan keresahan di masyarakat.

Khusus Pasal 27 ayat (3) UU ITE, pada esensinya penghinaan atau pencemaran nama baik ialah menyerang kehormatan, nama baik, atau martabat seseorang.Unsur "muatan penghinaan dan/atau pencemaran nama baik" yang diatur dalam Pasal 27 ayat (3) UU ITE mengacu pada KUHP. Esensi penghinaan atau pencemaran nama baik dalam UU ITE dan KUHP ialah tindakan menyerang kehormatan atau nama baik orang lain dengan maksud untuk diketahui oleh umum. Oleh karena itu, perbuatan mendistribusikan, mentransmisikan, membuat dapat diaksesnya dalam pasal ini haruslah dimaksudkan untuk menyerang kehormatan atau nama baik orang lain dengan maksud untuk diketahui oleh umum. ${ }^{\text {? }}$

Pasal pidana pencemaran nama baik yang terdapat dalam KUHP sebetulnya merupakan salah satu cara penjajah dalam membungkam kritik yang ingin menjatuhkan kekuasaannya. Banyak yang berpendapat bahwa KUHP di Indonesia saat ini sudah tidak relevan lagi digunakan di Indonesia. Oleh karena itu, Sudarto mengungkapkan bahwa usaha pembaruan Kitab Undang-undang Hukum Pidana atau KUHP didasarkan pada beberapa alasan, yaitu: Pertama, Dari aspek politis, KUHP Indonesia saat ini masih merupakan produk bangsa Asing yang pernah menjajah Indonesia. Hal tersebut masih menegaskan bahwa bangsa Indonesia hingga saat ini masih terjajah, dan memiliki kitab undang-undang sendiri merupakan kebanggaan negara yang merdeka. Kedua, dari aspek sosiologis, masyarakat menghendaki hukum yang mencerminkan nilai-nilai hidup di tengah-tengah mereka, sedang KUHP peninggalan Belanda tidak sesuai dengan nilai-nilai yang hidup dalam masyarakat Indonesia. Ketiga, secara praktis, biasanya negara jajahan mewarisi hukum negara yang menjajahnya beserta bahasa aslinya. KUHP Belanda diwarisi oleh bangsa Indonesia dengan bahasa aslinya, walaupun beberapa pakar hukum Indonesia telah menerjemahkan sesuai pemaham bahasa yang mereka miliki, tetapi tetap dikembalikan kepada bahasa

\footnotetext{
9 Josua Sitompul, Cyberspace, Cybercrimes, Cyberlaw : Tinjauan Aspek Hukum Pidana, (Jakarta: Tatanusa, 2012), dalam id.safenetvoice.org/2014/03/lagi-salah-kaprah-pasal-27ayat-3-uu-ite/
} 
aslinya ketika terjadi perbedaan pengertian. Hal ini menjadikan banyak aparat penegak hukum tidak mengerti sehingga salah dalam penerapannya disebabkan penafsiran yang menyimpang atau terjemahan yang kurang tepat. ${ }^{10}$

Menyatakan pendapat bukan berarti harus semena-mena dalam menyampaikannya. Harus ada etika yang harus dipenuhi dalam menyampaikannya. Hal tersebut dimaksudkan untuk melindungi Hak Asasi Manusia sebagaimana diatur dalam Konstitusi bahwa setiap orang berhak atas perlindungan diri pribadi, keluarga, kehormatan, martabat, dan harta benda yang dibawah kekuasaannya, serta berhak atas rasa aman dan perlindungan dari ancaman ketakutan untuk berbuat atau tidak berbuat sesuatu yang merupakan hak asasi. ${ }^{11}$

Kriteria yang lebih objektif untuk menilai hubungan antara muatan dari informasi atau dokumen elektronik yang dianggap menghina atau mencemarkan nama baik seseorang dan korban dapat dibangun berdasarkan konten dan konteks dari tiap-tiap kasus. Konten yang dipermasalahkan dapat dinilai dari sisi bahasa. Sedangkan konteks dapat dinilai dari sisi sosial maupun psikologi. ${ }^{12}$

Apabila dirinci jenis kemaslahatan dari sudut pandang hukum pidana Islam, maka akan didapati delapan jenis kebutuhan mendasar bagi manusia, yaitu kebutuhan pada: ${ }^{13}$ (a) agama yang terlindungi, (b) jiwa yang selamat, (c) akal yang sehat, (d) keturunan yang baik, (e) kehormatan yang dihargai, (f) harta yang terpelihara, (g) kesatuan/jamaah yang utuh, dan (h) pemerintahan yang berdaulat untuk melaksanakan tugas berbagai kebutuhan pokok sebelumnya.

Dalam perlindungan kebebasan atas akal yang sehat terdapat kebebasan dalam menyatakan pendapat, akan tetapi hal tersebut tidak boleh melanggar hak-hak lain yakni hak atas kehormatan yang harus dihargai.

Menurut Josep, pers atau media massa, tanpa etika bukan hanya tak mampu melayani kepentingan khalayak, melainkan justru akan menjadi bahaya bagi khalayak.

Kemudian diperkuat oleh Ketua Persatuan Wartawan Indonesia (PWI) pertama Mr. Sumanang pada tahun 1946, menyatakan bahwa etika

\footnotetext{
10 Sudarto, Hukum Dan Hukum Pidana, (Bandung; Alumni, 2007), 62

11 Josua Sitompul, Cyberspace, Cybercrimes, Cyberlaw: Tinjauan Aspek Hukum Pidana id.safenetvoice.org/2014/03/lagi-salah-kaprah-pasal-27-ayat-3-uu-ite/

12 Josua Sitompul, Cyberspace, Cybercrimes, Cyberlaw: Tinjauan Aspek.......

13 Muh. Tahmid Nur, "Maslahat Dalam Hukum Pidana Islam”, Jurnal Diskursus Islam, STAIN Palopo Sulut, Volume 1 Nomor 2, Agustus 2013, h. 301
} 
pers amat penting sebab bertalian dengan kewajiban wartawan dalam meliput berita dan mengabdi pada kepentingan tanah air dan bangsa. Pernyataan dari kedua tokoh pers tersebut, pada dasarnya mengindikasikan bahwa pers atau media massa dalam hal jurnalistik memerlukan orang-orang yang berintegritas tinggi dalam rangka membentuk karaktek etisnya. Pembentukan karaktek etis pers atau media massa melaksanakan kegiatannya yaitu mencari, memiliki, menyimpan mengelolah dan menyampaikan informasi kepada masyarakat luas, baik dalam bentuk tulisan, suara, gambar maupun data dan grafik dengan menggunakan segala jenis saluran yang tersedia, seyogyanya tidak terlepas dari etika dan menghormati norma-norma agama, seperti terdapat dalam UU No. 40 Thn 1999 Pasal 5 ayat (1) bahwa pers berkewajiban memberikan peristiwa dan opini dengan menghormati norma-norma agama dan rasa kesusilaan masyarakat serta asas praduga tak bersalah. ${ }^{14}$

Ketika House of Lords (Inggris) menyidangkan perkara "Reynolds lawan Times Newspaper" pada 28 Oktober 1999, Lord Nicholls mengingatkan para jurnalis bahwa kebebasan pers tidak absolut sifatnya. Pelaksanaan kebebasan pers bisa dibatasi oleh undang-undang dan memang perlu dibatasi terutama "for the protection of the reputation of others" (untuk melindungi martabat orang lain). Perlindungan terhadap martabat orang lain tidaklah kalah penting dibandingkan dengan perlindungan terhadap kebebasan pers. Menurut Lord Nicholls, demi kepentingan publik juga, reputasi pejabat publik sekali-sekali tidak boleh direndahkan dengan pernyataan atau laporan pers yang menyesatkan. ${ }^{15}$

Dalam undang undang Dasar 1945 disamping juga melindungi hak dalam kebebasan berpendapat juga melindungi harkat, martabat, kehormatan dan harga diri setiap pribadi seseorang. Dalam pasal $28 \mathrm{G}$ (1) disebutka bahwa "Seiap orang berhak atas perlindungan pribadi, keluarga, kehormatan, martabat, dan harta benda yang dibawah kekuasaannya, serta berhak atas aman, dan perlindungan dari ancaman ketakutan untuk berbuat atau tidak berbuat sesuatu yang merupakan hak asasi".

Perlindungan atas kehormatan juga telah diatur dalam UU No.39 Tahun 1999 tentang HAM dalam pasal 29 (1) disebutkan "Setiap orang berhak atas perlindungan diri pribadi, keluarga, kehormatan, martabat, dan hak miliknya".

\footnotetext{
${ }^{14}$ Hadiba Z. Wadjo, "Pencemaran Nama Baik Dalam Pemberitaan Pers" Jurnal Sasi Vol. 17 No.2 Bulan April - Juni 2011, h. 7

${ }^{15}$ www.HouseofLords-ReynoldsvTimesNewspapers.htm
} 
Dalam UU No 39 Tahun 1999 juga disebutkan bahwa hak-hak yang berhak digunakan dibatasi oleh hak-hak orang lain dan wajib menghormati, melindungi dan melaksanakan sepenuhnya hak-hak orang lain itu yang menjadi kewajiban kita. Sebagaimana yang dijelaskan dalam:

\section{Pasal 35,}

"Setiap orang berhak hidup di dalam tatanan masyarakat dan kenegaraan yang damai, aman, dan tenteram, yang menghormati, melindungi dan melaksanakan sepenuhnya hak asasi manusia dan kewajiban dasar manusia sebagaimana diatur dalam Undang-undang ini". ${ }^{16}$

\section{Pasal 69}

1. Setiap orang wajib menghormati hak asasi manusia orang lain, moral, etika, dan tata tertib kehidupan bermasyarakat, berbangsa, dan bernegara.

2. Setiap hak asasi manusia seseorang menimbulkan kewajiban dasar dan tanggungjawab untuk menghormati hak asasi orang lain serta menjadi tugas Pemerintah untuk menghormati, melindungi, menegakkan, dan memajukannya. ${ }^{17}$

\section{Pasal 70}

"Dalam menjalankan hak dan kebebasannya, setiap orang wajib tunduk kepada pembatasan yang ditetapkan oleh Undang-undang dengan maksud untuk menjamin pengakuan serta penghormatan atas hak dan kebebasan orang lain dan untuk memenuhi tuntutan yang adil sesuai dengan pertimbangan moral, keamanan, dan ketertiban umum dalam suatu masyarakat demokratis",18

Oleh karena itu dalam menyampaikan pendapat disamping harus menjaga hak diri sendiri juga harus menghormati hak-hak orang lain. Hak orang lain berarti kewajiban atas diri kita. Orang lain berhak memperoleh perlindungan atas kehormatan diri merupakan kewajiban untuk menjaga kehormatan itu.

Kebebasan menyatakan pendapat harus diimbangi dengan menghormati harga diri setiap individu. Karena dalam islam, meskipun telah sesuai fakta melakukan tidak kesalahan, kita tetap harus menghormati harga diri orang tersebut. Tidak boleh dihina ataupun direndahkan martabatnya.

\footnotetext{
16 UU Nomor 39 Tahun 1999 Tentang HAM

17 UU Nomor 39 Tahun 1999 Tentang HAM

18 UU Nomor 39 Tahun 1999 Tentang HAM
} 


\section{Analisis Maqậid Sharî’ah terhadap Pencemaran Nama Baik yang Melanggar HAM}

Pada dasarnya HAM dalam Islam terpusat pada lima hal pokok yang terangkum dalam al-darüriyat al-khamsah atau yang disebut juga al-huqüq al-insâniyyah fi al-islâm (hak-hak asasi manusia dalam Islam). Konsep ini mengandung lima hal pokok yang harus dijaga oleh setiap individu, yaitu bifdru al-dîn (penghormatan atas kebebasan beragama), hifdzu al-mâl (penghormatan atas harta benda), hifdzu al-nafs wa al-ird (penghormatan atas jiwa, hak hidup dan kehormatan individu) bifdæu al-'aql (penghormatan atas kebebasan berpikir) dan hifdzu al-nasl (keharusan untuk menjaga keturunan). Kelima hal pokok inilah yang harus dijaga oleh setiap umat Islam supaya menghasilkan tatanan kehidupan yang lebih manusiawi, berdasarkan atas penghormatan individu atas individu, individu dengan masyarakat, masyarakat dengan masyarakat, masyarakat dengan negara dan komunitas agama dengan komunitas agama lainnya.

Islam juga telah melindungi hak dalam berpendapat. Dalam islam, juga terdapat konsep kebebasan dalam menyampaiakan kritik dan pendapat. Hak untuk bicara tersebut dengan melakukan al Amru bil ma'ruf wan Nahyu anil mungkar yang mencakup kebebasan memberi kritik (Q.S Ali Imran: 104)
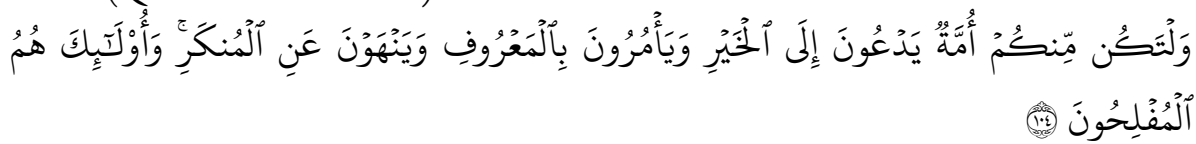

Artinya: "dan hendaklah ada di antara kamu segolongan umat yang menyeru kepada kebajikan, menyurub kepada yang ma'ruf dan mencegah dari yang munkar ${ }^{19}$; merekalah orang-orang yang beruntung".(QS. Ali Imron: 104$)^{20}$

Akan tetapi Syariat Islam tidak semata-mata memberikan kebebasan berekspresi serta memberikan kritik. Kebebasan dalam berbicara bukan merupakan kebebasan yang absolut, akan tetapi kebebasan dalam berbisara ini tetap tercakup dalam lingkup batas-batas kepantasan sosial dan dapat mengotori syariat Islam.

Dalam kasus Bersihar Lubis, seorang kolumnis senior yang menulis opini pada kolom Koran Tempo 17 Maret 2007 dengan judul "Kisah Interogator yang Dungu" merupakan suatu bentuk kebebasan berekspresi dalam menyampaikan pendapat.

${ }_{19}$ Ma'ruf: segala perbuatan yang mendekatkan kita kepada Allah; sedangkan Munkar ialah segala perbuatan yang menjauhkan kita dari pada-Nya.

20 Departemen Agama RI, al-Qur'an dan Terjemahannya, (Bandung: Penerbit Diponegoro, 2012), Qs. Ali Imron: 104 
Tulisan Bersihar Lubis tersebut telah diakui dalam jaminan Hak Asasi Manusia atas kekebasan menyatakan pendapat. Akan tetapi sayangnya, kritikan yang sebenarnya bersifat membangun terhadap sebuah institusi malah menjadikan dirinya sebagai terdakwa dalam kasus pencemaran nama baik.

Yang menjadi penyebab dalam kasus pencemaran nama baik adalah pengunaan kata "dungu" yang dalam kamus Bahasa Indonesia, dungu berarti sangat tumpul otaknya; tidak cerdas; bebal; bodoh. ${ }^{21} \mathrm{Hal}$ inilah yang dianggap sebagai penghinaan martabat dan harga diri seseorang.

Dalam kasus yang dialami oleh kolumnis tersebut termasuk dalam kategori pencemaran nama baik karena telah memenuhi unsur-unsurnya yaitu dengan menggunakan kata-kata yang menyerang harga diri, harkat dan martabat yang tidak sesuai dengan soial masyarakat sekitarnya (dengan penggunaan kata "dungu"). Disamping itu juga memenuhi unsur dengan sengaja dipublikasikan atau disebarkan kepada masyarakat umum melalui media cetak.

Setiap jiwa manusia pasti mempunyai akal, dalam menggunakan akal telah dijamin lewat sebuah kebebasan berpendapat. Akan tetapi dalam jiwa terdapat suatu kehormatan yang harus dihormati oleh setiap orang. Sementara itu, terdapat tiga kepentingan hukum yang dilindungi oleh hukum pidana, yaitu kepentingan individu, kepentingan masyarakat, dan kepentingan negara. Dalam hal kepentingan hukum individu, maka yang dilindungi atau dijamin oleh hukum pidana dimana pun, termasuk yang diatur dalam KUHP, adalah jiwa (leven), badan (lijt), kemerdekaan (vrijheid), dan harta benda (vermogen). Dalam perkembangannya, kehormatan (eer) juga menjadi kepentingan hukum yang dilindungi oleh hukum pidana karena setiap manusia mempunyai perasaan terhadap kehormatan (eergevoel). Sehingga setiap manusia dijamin bahwa kehormatannya tidak akan diperkosa atau dilanggar. Hak atas perlindungan terhadap kehormatan ini menjadi objek dari tindak pidana penghinaan (de mens heeft het recht dat zijn eer niet zal worden gekrenkt). ${ }^{22}$

Sejalan dengan uraian di atas, Pasal 28G UUD 1945 serta pasal 29 UU No.39 Tahun 1999 tentang HAM juga dengan tegas mengakui bahwa

\footnotetext{
${ }^{21}$ Kamus Besar Bahasa Indonesia, KBBI offline 1.5.1. "dungu"

22 Mahkamah Konstitusi Republik Indonesia, Ikbtisar Putusan Perkara Pengujian UndangUndang dan Sengketa Kewenangan Lembaga Negara Mabkamah Konstitusi 2008-2009, (Jakarta: Sekretariat Jenderal dan Kepaniteraan Mahkamah Konstitusi, Cetakan Pertama, Agustus 2010), ISBN: 978-602-8308-27-4, h. 23
} 
kehormatan, demikian pula martabat, sebagai hak konstitusional dan oleh karenanya dilindungi oleh konstitusi.

Tujuan Syari'ah Islam juga tidak lepas dari perlindungan atas kehormatan. Hal itu terlihat dari Maqâsid Sharîah itu sendiri, dimana dalam Maqâșid Sharîah ada 5 kebebasan yang harus dilindungi dan dijamin. Karena apabila kelima hak ini diabaikan, maka seorang manusia itu tidak akan ada artinya sebagai seorang manusia itu sendiri. Kelima hal tersebut adalah:

Pertama, Hifdzu al-din (penghormatan atas kebebasan beragama). Dalam memeluk agama, Bahkan Islam memberi perlindungan kepada pemeluk agama lain untuk menjalankan agamanya sesuai dengan keyakinannya $^{23}$

Sesuai dengan firman Allah SWT.

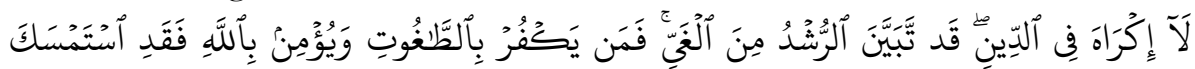

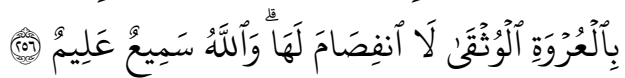

Artinya: "Tidak ada paksaan untuk (mamasuki) agama (islam), sesungubnya telah jelas yang benar daripada jalan yang sesat”.(QS.Al-Baqarah(2): 256).

Islam mengajarkan kebebasan dalam beragama, tidak memaksakan agama karena agama adalah merupakan suatu hidayah langsung dari Allah. Dalam beragama tidak boleh dengan menggunakan kekerasan. Karena ada jaminan hak-hak yang terlanggar di dalamnya.

Kedua, Hifdzu al-mal (penghormatan atas harta benda). Islam menghormati harta yang telah menjadi hak milik yang sah. Dalam Islam di jamin adanya kebebasan mencari harta dengan jalan yang benar. Oleh karena itu tidak boleh mencari harta dengan jalan yang batil yang tidak dibenarkan oleh syara' tidak lain karena melindungi kebebasan orang lain dalam menggunakan haknya dengan baik. Hal ini sejalan dengan ayat alQur'an:
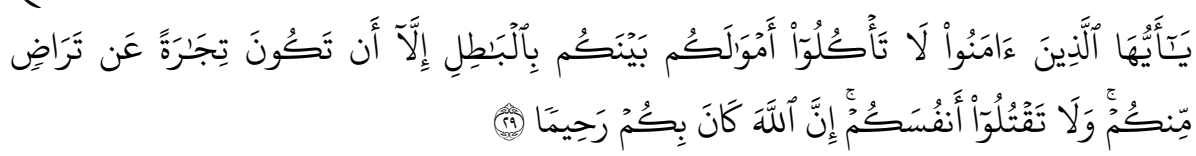

Artinya: "Hai orang-orang yang beriman, janganlah kamu saling memakan harta sesamamu dengan jalan yang batil, kecuali dengan jalan perniagaan yang Berlaku dengan suka sama-suka di antara kamu. dan janganlab kamu

23 Ramin Abd. Wahid, "Maqashid al-Syari'ah dan Penerapan Hak Asasi Manusia dalam Masyarakat Islam" Jurnal Salam Poltekom Malang, Vol 15 No 1, Juni 2012, 127 
membunuh dirimu24; Sesunggubnya Allah adalah Maha Penyayang kepadamu”. (QS. An Nisa: 29)

Ketiga, Hifdru al-nafs wa al-ird (penghormatan atas jiwa, hak hidup dan kehormatan individu). Jaminan keselamatan atas hak hidup telah dijamin haknya oleh Islam. Termasuk dalam pengertian umum dari jiwa ini adalah jaminan keselamatan nyawa, anggota badan dan dalam jiwa terkandung juga terjaminnya kehormatan kemanusian. Harga diri seorang manusia melekat kuat pada jiwa setiap individu, maka dari itu harus dihormati dan beri kebebasan dengan cara dihargai. ${ }^{25}$ Sebagaimana QS. An Nisa: 29 di atas.

Dalam kitab salaf dijelaskan bahwa:

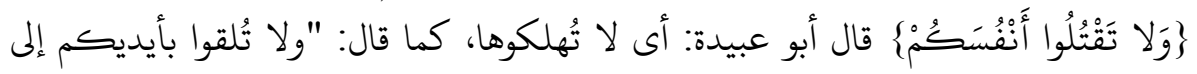

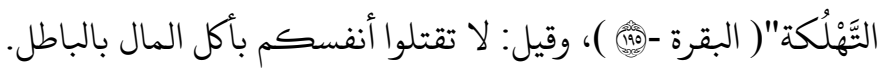

Dalam keterangan tersebut tidak diperkenankan membunuh jiwa, hal ini bisa berarti nyawa ataupun harga diri yang masuk melekat dalam diri seseorang. Tidak diperbolehkan merusak jiwa, harga diri meskipun dengan memakai harta dengan cara yang tidak baik. Hal ini menimbulkan harga diri menjadi tercemar dan tercoreng akibat perbuatan tersebut. Merusak diri sendiri saja tidak boleh apalagi merusak harga diri orang lain. $^{26}$

Keempat, Hifdzu al-'aql (penghormatan atas kebebasan berpikir). Terjaminnya akal pikiran dengan memberi kebebasan terhadap akal untuk melakukan dengan baik apa yang telah menjadi tugasnya. Dalam bifdzu al-'aql terdapat kebebasan untuk berpikir sesuai dengan jalan pikirannya. Hal tersebut termasuk juga kebebasan dalam menyampaikan pendapat maupun kritikan. Karena pengekangan terhadap akal menjadi sebab awal dari kerusakan yang menyebabkan orang yang bersangkutan tidak berguna ditengah masyarakat.

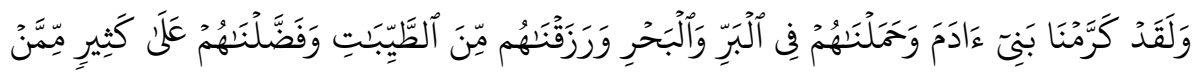

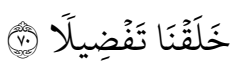

\footnotetext{
${ }^{24}$ Larangan membunuh diri sendiri mencakup juga larangan membunuh orang lain, sebab membunuh orang lain berarti membunuh diri sendiri, karena umat merupakan suatu kesatuan.

25 Ramin Abd. Wahid, Maqashid al-Syari'ah dan Penerapan..., 128.

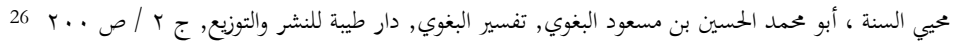


Artinya: "dan Sesunggubnya telab Kami muliakan anak-anak Adam, Kami angkut mereka di daratan dan di lautan ${ }^{27}$, Kami beri mereka rezki dari yang baik-baik dan Kami lebibkan mereka dengan kelebihan yang sempurna atas kebanyakan makbluk yang telah Kami ciptakan”. (QS. Al Isra: 70)

Kelima, Hifdzu al-nasl (keharusan untuk menjaga keturunan). Dalam hal ini terdapat kebebasan untuk memperoleh keturunan, kebebasan dalam melangsungkan perkawinan sesuai dengan agama massing-masing. Dalam melindungi hak untuk menjaga keturunan diperlukan suatu proses yang sesuai dengan syari'at yakni melewati proses pernikahan yang sah secara agama.

Mencemarkan nama baik seseorang dengan merendahkan harkat martabat, harga diri seseorang merupakan pelanggaran HAM secara ringan. Pencemaran nama baik dalam islam termasuk juga kedalam istilah gbibah. Seperti yang dijelaskan dalam al-Qur'an:

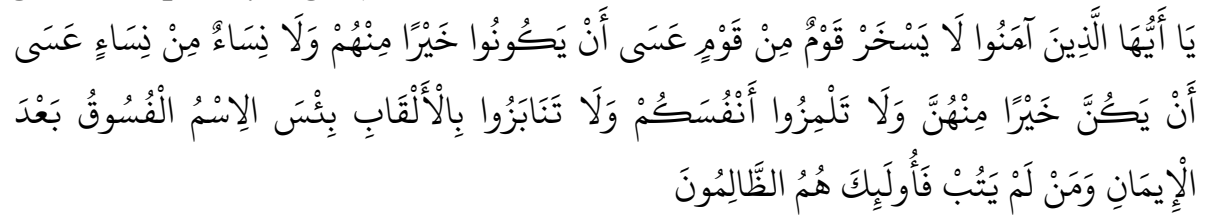

Artinya: "Hai orang-orang yang beriman, janganlah sekumpulan orang laki-laki merendabkan kumpulan yang lain, boleh Jadi yang ditertawakan itu lebih baik dari mereka. dan jangan pula sekumpulan perempuan merendabkan kumpulan lainnya, boleh Jadi yang direndabkan itu lebib baik. dan janganlah suka mencela dirimu sendiri ${ }^{28}$ dan jangan memanggil dengan gelaran yang mengandung ejekan. seburuk-buruk panggilan adalab (panggilan) yang buruk sesudah iman ${ }^{29}$ dan Barangsiapa yang tidak bertobat, Maka mereka Itulah orang-orang yang zalim" (QS. alHujurât: 11$)^{30}$.

\footnotetext{
${ }^{27}$ Maksudnya: Allah memudahkan bagi anak Adam pengangkutan-pengangkutan di daratan dan di lautan untuk memperoleh penghidupan.

28 Jangan mencela dirimu sendiri Maksudnya ialah mencela antara sesama mukmin karana orang-orang mukmin seperti satu tubuh.

29 Panggilan yang buruk ialah gelar yang tidak disukai oleh orang yang digelari, seperti panggilan kepada orang yang sudah beriman, dengan panggilan seperti: Hai fasik, Hai kafir dan sebagainya.

30 Departemen Agama RI, al-Qur'an dan Terjemahannya, (Bandung: Penerbit Diponegoro, 2012), Qs. Hujurât: 11
} 
Allah melarang orang-orang mukmin untuk tidak memanggil saudaranya yang lain dengan julukan yang buruk terutama yang tidak disukai. $^{31}$

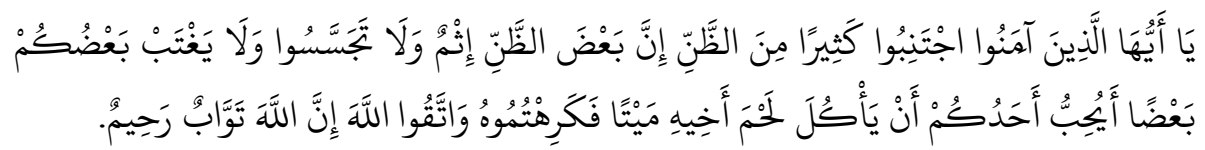

Artinya: "Hai orang-orang yang beriman, jaubilab kebanyakan purba-sangka (kecurigaan), karena sebagian dari purba-sangka itu dosa. dan janganlah mencari-cari keburukan orang dan janganlah menggunjingkean satu sama lain. Adakah seorang diantara kamu yang suka memakan daging saudaranya yang sudah mati? Maka tentulah kamu merasa jijik kepadanya. dan bertakwalab kepada Allah. Sesunggubnya Allah Maha Penerima taubat lagi Maha Penyayang. (QS. al-Hujurât: 12) ${ }^{32}$

Dalam Islam seorang mukmin dilarang untuk su'udzon terutama kepada sesama mukmin yang lain. Karena berburuk sangka merupakan perbuatan menyakiti orang lain dan merupakan perbuatan dosa. Dalam hadith ini memuat larangan menggunjing, mencari-cari keburukan orang lain dan larangan berburuk sangka. Karena berburuk sangka adalah ucapan yang paling bohong.

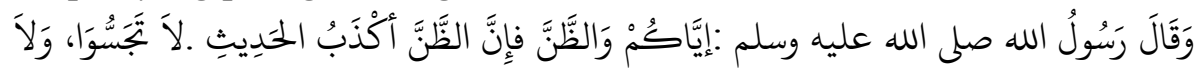

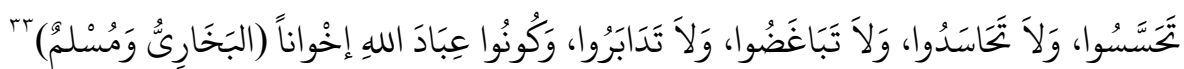

Dalam bermasyarakat jangan sampai membuka cela orang lain. Hal itu akan menimbulkan rasa sakit hati bagi yang mempunyai aib. Dalam islam apabila mengetahui orang lain melakukan aib secara diam diam, kita tidak boleh memberitahukannya kepada orang lain agar orang yang melakukan tidak merasa malu. Sikap ini bukan berarti membiarkan orang berbuat dosa akan tetapi menjaga harga diri orang tersebut dengan mengingatkan agar tidak mengulangi lagi tanpa menyebarkan kepada khalayak umum. Termasuk dari ghibah adalah menyebutkan sesuatu yang tidak disukai oleh orang yang kita bicarakan, baik dari sisi agama, dunia, bentuk tubuhnya, akhlaq, keluarga, harta, istri maupun anaknya.

Ada tiga termasuk kategori gbibah: (a) Membicarakan orang lain dengan mengucapkan sesuatu yang tidak disukai. (b) Menyampaikan pembicaraan yang tidak disukai kepada orang yang dituju. Dan (c)

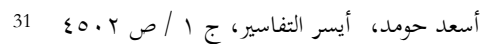

32 Departemen Agama RI, al-Qur'an dan Terjemahannya, (Bandung: Penerbit Diponegoro, 2012), Qs. Hujurât: 12

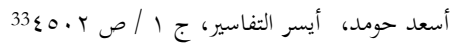


membicarakan orang lain meskipun perkataan tersebut tidak dalam kategori tidak disukai oleh orang yang dibicarakan. ${ }^{34}$

Dari penjelasan diatas, dapat dijelaskan bahwa dalam kasus bersihar lubis yang menyatakan haknya atas kebebasan berpendapat memang telah diakui di dalam syari'ah maupun oleh konstitusi dalam undangundang negara. Konstitusi menjamin hak-hak tersebut dan karena itu negara wajib melindunginya. Namun, pada saat yang sama negara pun wajib melindungi hak konstitusional lain yang sama derajatnya dengan hak-hak tadi, yaitu hak setiap orang atas kehormatan dan martabat sebagaimana diatur Pasal 28G UUD 1945.

Bahwa nama baik, martabat, atau kehormatan seseorang adalah salah satu kepentingan hukum yang dilindungi oleh hukum pidana karena merupakan bagian dari hak konstitusional warga negara yang dijamin oleh UUD 1945 maupun hukum internasional, dan karenanya hukum pidana dapat memberikan ancaman sanksi pidana tertentu terhadap perbuatan yang menyerang nama baik, martabat, atau kehormatan seseorang,

Karena adanya kewajiban untuk melindungi hak konstitusional lain itulah, yakni hak atas kehormatan dan martabat, maka negara dibenarkan melakukan pembatasan terhadap hak atas kebebasan menyatakan pikiran dan sikap sesuai dengan hati nurani, hak untuk mengeluarkan pendapat dan bebas berkomunikasi tersebut, sebagaimana secara tegas dinyatakan dalam Pasal 28J ayat (2) UUD 1945.

Hal ini sesuai dengan prinsip dasar dalam maqasid Shariah yang berupa hifdzu al-nafs wa al-ird (penghormatan atas jiwa, hak hidup dan kehormatan individu). Meskipun dalam maqasid dijamin adanya kebebasan menyatakan pikiran dalam prinsip hifdzu al-'aql (penghormatan atas kebebasan berpikir), akan tetapi tidak boleh melanggar hak prinsip yang lain yakni kehormatan dan harga diri.

Prinsip kebebasan berbicara dan mengutarakan pendapat secara alamiah dibatasi oleh hak-hak lain yakni kebebasan untuk mendapatkan harga diri dan kehormatan jiwa.

Akan tetapi negara juga tidak boleh dengan semena-mena memvonis suatu kritikan dengan tuduhan pencemaran nama baik. Sebaiknya diberi batasan kritik yang bagaimana yang harus dikategorikan dalam pencemaran nama baik, misalkan suatu opini yang telah mengganggu stabilitas keamanan nasional, opini yang meresahkan masyarakat dan yang telah mengancam kesatuan dan persatuan bangsa. Suatu batasan

أسعد حومد، أيسر التفاسير، ج | /ص ب. 34 
yang dapat mengganggu keamanan nasional dan yang tidak sesuai dengan etika kebangsaan. Karena tidak sedikit berawal dari kritiklah kita dapat membangun sesuatu menjadi lebih baik.

Oleh sebab itu, dibutuhkan keseimbangan check and balance dalam menjalankan dan menggunakan hak-hak kebebasan yang telah diberikan. Agar tercipta suatu proses yang stabil dan saling menghargai.

\section{Kesimpulan}

Undang-undang telah menjamin adanya hak kebebasan dalam menyampaikan suatu pendapat. Yakni dalam pasal 28 E, F UUD 1945 dan juga pasal 14, 23, 24, 25, UU No.39/1999 tentang HAM. Hal itu juga telah sesuai dengan prinsip dasar hifdz 'Aql dalam maqasid shari'ah dalam hukum islam. Namun dalam hal menggunakan hak untuk menyampaikan pendapat harus sesuai dengan nilai-nilai atau norma yang tengah berlaku dimasyarakat. Harus disampaikan dengan baik penuh etika sehingga tidak melanggar kebebasan-kebebasan atau jaminan hak yang lain.

Menyampaikan suatu pendapat tidak boleh menggunakan bahasa berlebihan yang menyebabkan keresahan masyarakat, sehingga dapat mencemarkan nama baik seseorang. Dalam KUHP dijelaskan bahwa tindak pidana pencemaran nama baik termasuk dalam pelanggaran pidana. Hal ini tercantum dalam pasal 310-321 dalam Bab XVI tentang penghinaan.

Hak dalam menyatakan kebebasan pendapat yang dijamin oleh undang-undang telah dibatasi oleh pasal-pasal yang tercantum dalam KUHP yaitu terkait dengan pasal-pasal pencemaran nama baik, fitnah, penghinaan dan tuduhan palsu. Pasal pencemaran nama baik masih tetap diperlukan untuk menjaga kehormatan dan nama baik tiap anggota masyarakat

Undang-undang juga telah melindungi hak konstitusional yang lain yakni hak untuk mendapatkan perlindungan kehormatan, martabat dan harga diri yang melekat dalam jiwa setiap manusia di dalam UUD 1945 pasal 28 G, dan pasal 29 UU No.39/1999 tentang HAM.

Antara prinsip kebebasan berpendapat dalam UU 39/1999 tentang HAM dengan pasal Pencemaran Nama Baik dalam KUHP ternyata saling membatasi satu sama lain. Pasal Pencemaran Nama baik dalam KUHP membatasi kebebasan menyampaikan pendapat agar tidak sampai melanggar prinsip hak manusia yang lain diantarana adalah kehormatan. Oleh karena itu antara hak untuk mendapatkan kebebasan dan kehormatan harus berjalan seimbang. Menghormati harga diri orang lain 
tidak mematikan dan tidak melanggar kebebasan berpendapat. Akan tetapi Kebebasan berpendapat yang kebablasan bisa melanggar harga diri orang lain. Salah satu sisi diberi kebebasan menyatakan pendapat, disisi yang lain juga harus menghormati hak kebebasan orang lain untuk mendapatkan kehormatan dan harga diri. Dalam arti, hak orang lain untuk dihormati adalah kewajiban kita untuk mengormati. Maka menyampaikan pendapat harus dengan memakai etika agama maupun sosial sesuai dengan kondisi masyarakat.

Ketika semua bisa berjalan seimbang akan tercipta suatu kondisi yang stabil yang dapat dengan pesat membangun kehidupan berbangsa dan bernegara, karena terjaminnya hak kebebasan menyatakan pendapat dan kehormatan yang dihargai secara penuh bisa berjalan seimbang.

Salah satu contoh kasus yang dialami oleh bersihar lubis merupakan sebuah pelajaran bagi kita semua dalam mengekspresikan kebebasan pendapat. Dalam menyatakan pendapat harus dengan memakai kata-kata yang menurut etika masih pantas untuk dipublikasikan secara umum, harus menjaga etika dan estetika dalam berbicara maupun menyampaikan pendapat. Tidak merusak harga diri orang lain dan tidak menimbulkan keresahan di masyarakat. Karena menyerang harga diri seseorang dengan kata-kata yang tidak pantas dan tidak sopan juga telah dilindungi dalam konsep Maqâșid Sharîah dalam islam, yakni perlindungan dan jaminan kebebasan atas jiwa dan kehormatan seseorang (bifdz nafs wa al-irdl).

Islam juga melindungi dan memberikan kebebasan berpendapat ( $h i f d z$ al 'Aql) juga memberikan perlindungan atas kebebasan mendapatkan kehormatan. (bifdz, nafs wa al-irdl). Dalam menggunakan hak kebebasan menyatakan pendapat seringkali terjerumus kedalam pidana pencemaran nama baik. Seringkali diadukan oleh sekelompok orang yang anti terhadap kritik dengan mencari celah pencemaran nama baik. Oleh karena itu Negara harus membatasi dengan jelas batas-batas yang harus dipatuhi dalam berekspresi. Agar kedua hak ini bisa berjalan dengan beriringan antara hifdz al 'Aql dan bifdz nafs wa al-irdl.

Harus adanya batasan-batasan dalam menyatakan pendapat yang masuk ranah pidana misalkan; mengganggu stabilitas keamanan nasional, meresahkan masyarakat, mengganggu keamanan sekitar, mengancam keutuhan dan persatuan bangsa, dan melanggar etika-etika yang berkembang dimasyarakat, dalam hal ini sesuai dengan adat masingmasing daerah.

Untuk batasan yang lebih objektif terkait menghina atau mencemarkan nama baik seseorang dan korban dapat dibangun berdasarkan konten dan konteks dari tiap-tiap kasus. Konten yang 
dipermasalahkan dapat dinilai dari sisi bahasa. Sedangkan konteks dapat dinilai dari sisi sosial maupun psikologi.

\section{Daftar Pustaka}

Eddy OS Hiariej, (Guru Besar Hukum Pidana Fakultas Hukum UGM), Memahami Pencemaran Nama Baik, dalam http://beniharmoniharefa.blogspot.com/2011/03/ memahamipencemaran-nama-baik.html, Dimuat pada Harian KOMPAS, 5 Juni 2009

http://www.hukumonline.com/klinik/detail/lt517f3d9f2544a/perbuata

n-perbuatan-yang-termasuk-pencemaran-nama-baik

http:/ /www.kompasiana.com/hoshizora/pelanggaran-ham-pencemarannama-baik-seseo rang-kelompok-di-sosmed.

Josua Sitompul, Cyberspace, Cybercrimes, Cyberlaw: Tinjauan Aspek Hukum Pidana, (Jakarta: Tatanusa, 2012), dalam id.safenetvoice.org/2014/03/lagi-salah-kaprah-pasal-27-ayat-3-uuite/

Lesmana, Tjipta. Pencemaran Nama Baik dan Kebebasan Pers Antara Indonesia dan Amerika, Jakarta: Rika Press, 2005.

Mahfud, Moh. MD. Demokrasi Dan Konstitusi Di Indonesia, Studi Tentang Interaksi Politik Dan Kebidupan Ketatanegaraan. Yogjakarta: Liberty, 2000.

Mahkamah Konstitusi Republik Indonesia. Ikbtisar Putusan Perkara Pengujian Undang-Undang dan Sengketa Kewenangan Lembaga Negara Mabkamah Konstitusi 2008-2009, Jakarta: Sekretariat Jenderal dan Kepaniteraan Mahkamah Konstitusi, Cetakan Pertama, Agustus 2010, ISBN: 978-602-8308-27-4.

Sudarto. Hukum Dan Hukum Pidana. Bandung: Alumni, 2007.

Tahmid, Muh. Maslahat Dalam Hukum Pidana Islam. Jurnal Diskursus Islam, STAIN Palopo Sulut, Volume 1 Nomor 2, Agustus 2013.

Undang-Undang Nomor 11 Tahun 2008 tentang Informasi dan Transaksi Elektronik.

UU No. 26 Tahun 2000 tentang Pengadilan HAM.

UU RI Nomor 39 Tahun 1999 tentang Hak Asasi Manusia.

UUD NRI Tahun 1945

Wadjo, NurHadiba Z. "Pencemaran Nama Baik Dalam Pemberitaan Pers" Jurnal Sasi, Vol. 17 No.2 Bulan April - Juni 2011.

Wahid, Ramin Abd. "Maqashid al-Syari'ah dan Penerapan Hak Asasi Manusia dalam Masyarakat Islam" Jurnal Salam Poltekom Malang, Vol 15 No 1, Juni 2012. 